Original Research Paper

\title{
Modeling the Evolution of Nitrate Pollution of Groundwater in the Plain of Western Middle Cheliff
}

\author{
${ }^{1}$ Nessrine Belmiloud and ${ }^{2}$ Naïma Bettahar \\ ${ }^{I}$ Water and Environment Laboratory, Institute of Agronomic Sciences, University of Chlef, Chlef, Algeria \\ ${ }^{2}$ Water and Environment Laboratory. \\ Faculty of Civil Engineering and Architecture, University of Chlef, Chlef, Algeria
}

Article history

Received: 22-02-2015

Revised: 06-12-2015

Accepted: 11-01-2016

Corresponding Author: Nessrine Belmiloud

Water and Environment

Laboratory, Institute of

Agronomic Sciences, University

of Chlef, Chlef, Algeria

Email: n.belmiloud@univ-chlef.dz

\begin{abstract}
Groundwater constitute a potential source of drinking water supply and should, consequently, benefit from the necessary protection against the various forms of pollutions, particularly those diffuse of agricultural origin. The plain of Western Middle Cheliff which contains an important resource in groundwater supplying the whole population of the province of Chlef and contributing to the satisfaction of the need for irrigation because of the inaccessibility of most crops surface water distributed in the collective network, is confronted with risks of contamination resulting mainly from agricultural practices that generate high levels of nitrates in these waters. The part of the domestic effluents rejected often without purification and of the industrial activity is not to be neglected. Nitrate leaching to groundwater is influenced, among others, soil type, crop type and fertilization. To see the spatial evolution of nitrate pollution in groundwater of the plain, a map was established by ordinary kriging for the results of the campaign carried out in May of 2012. It appears clearly that the lowest nitrate levels cover the central part, the north and the east of the ground-water sheet under fine-textured soils. Conversely, the most affected grounds are concentrated around the edges, especially in the west, in more permeable soils receiving intensive nitrogenous fertilization. The annual contributions of nitrogen on the soils of the plain are estimated at $1958,83 \mathrm{~T}$ among which $95 \%$ are attributed to nitrogen fertilizers and the rest in the irrigation water.
\end{abstract}

Keywords: Groundwater, Contamination, Nitrates, Fertilizer, Irrigation

\section{Introduction}

Water is an essential element for life and important for human activities. It can be rare in some places, such as arid and semi-arid areas and with poor quality in other places. It is certain that the increase in water demand for human activities add more constraints on this resource. In addition, natural factors such as drought or geological constraints have an effect on the drinking water supply and distribution. Therefore, it is essential to quantify and analyze the quantity and quality of water supplies and to find ways to manage this resource to ensure the sustainability. There are many types of pollution that can affect the quality of this resource; however, those that are attributed to human activities are the most menacing. In particular, the pollution related to the presence of nitrates which origin comes from agricultural practices.
In agriculture, chemical fertilizers are used to increase crop yields and responsible for a massive soil pollution, especially nitrates, which are the major cause of pollution of groundwater that represent the principal source of drinking water reservoirs (Feng et al., 2005; Elmi et al., 2004). There are three main types of chemical fertilizer: Nitrogen, phosphate and potash. They provide the nutrients that plants need to grow which may be missing in the soils overly exploited. The increased nitrate levels in water, which is not desirable neither for the humans nor for the environment, represents today a serious problem for many countries, whatever their level of development; this pollution is menacing in countries where the population is increasing rapidly, where development requests are considerable and governments have other investment priorities (Shiklomanov, 1997). 
Today, $66 \%$ of the nitrate pollution of water is attributed to agriculture. Land application of crops provides massive doses of nitrogen fertilizer. Nitrates are highly soluble in water, when plants do not consume them, they can easily seep into the ground and gradually reach the groundwater. About $70 \%$ of nitrogen fertilizers used in agriculture are lost into the environment as nitrate (Yapo et al., 2009) that can be found in surface water and groundwater.

Before the $1950 \mathrm{~s}$, the nitrate concentrations of water did not exceed $1 \mathrm{mg} \mathrm{L}^{-1}$. At present, it easily exceeds the international standard set at $50 \mathrm{mg} \mathrm{L}^{-1}$. In Lusaka (capital of Zambia), Nkhuwa (2003) and De Waele et al. (2004) showed the presence of nitrate (contents more

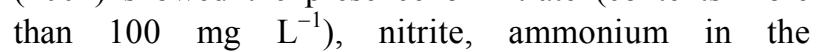
groundwater contained in karst formations, a particularly vulnerable geological environment. These authors showed by analyzing nitrate nitrogen, the presence of these nitrogen compounds demonstrates pollution by organic matter decomposition from latrines and septic tanks. Isotopic studies (Nkhuwa and Tembo, 1998) indicate that susceptibility of aquifers to pollution appears mainly during the rainy season (November to April), at the time of aquifer recharge.

In Algeria, studies in some regions have found that the nitrate concentration is usually above $50 \mathrm{mg} \mathrm{L}^{-1}$, standard recommended by the World Health Organization (WHO). Sidi Bel-Abbes, Birkhadem (Algiers), Chlef and the plain of Mitidja (Blida) are concrete examples where the nitrate concentration in 1990 already exceeds the $260 \mathrm{mg} \mathrm{L}^{-1}$ (Salem et al., 2007). In 2004, the concentration reaches $570 \mathrm{mg} \mathrm{L}^{-1}$ in Oued Mazzouze (Skikda) according to Chabour (2004). According to Boudjadja et al. (2003), nitrate concentration is between $77 \mathrm{mg} \mathrm{L}^{-1}$ and $175 \mathrm{mg} \mathrm{L}^{-1}$ in the Chlef plains, $100-200 \mathrm{mg} \mathrm{L}^{-1}$ in the Sidi BelAbbes plains and more than $50 \mathrm{mg} \mathrm{L}^{-1}$ in the wells of Mazafran (Algiers) and same concentration range in the half of the wells of the Mitidja plain, in which the enrichment of nitrates is related to agricultural activities and urban domestic waste, especially when the superficial layers are permeable. Also the use of nitrogen fertilizer in a quantity that exceed the needs of plants. Indeed, our farmers use an important quantity of nitrogen fertilizer.

Other studies accomplished at the plain of Annaba (Debieche, 2002; Djabri, 1996; Kherici, 1993; Nafa, 1985) and in the Mitidja plain as part of a long follow-up (1985 to 1993), conducted by National Agency of Hydraulic Resources (NAHR) in Blida on wells that recorded high concentrations of nitrate, at the high Cheliff plains (Ikhlef, 2008) and at the Western Middle Cheliff plains (Bettahar et al., 2009). The exploitation of waters of the plain Western Middle Cheliff situated in the North of Algeria represent $86 \%$ of the production of drinking water and ensures equalization throughout the province of Chlef (ABH-CZ, 2012). This plain characterized by intensive agricultural activity in which vegetable gardening is the biggest consumer of nitrogen from mineral fertilizer, provide waters with high nitrate concentration $\left(>100 \mathrm{mg} \mathrm{L}^{-1}\right)$. The concerned areas are located on the edges of the valley where the level of intensification of nitrogen fertilization is the highest in the most permeable soils (Bettahar et al., 2009). The area of study has experienced during the last years, an economic expansion, particularly agricultural and that after the application of the National Program of Agricultural Development (NPAD) in 2000 and the application of the National Fund for Regulation of Agricultural Development (NFRAD) in 2001. This has increased the water demands and exposed the resource to various pollutions from agricultural activities; including pollution caused by nitrates. Assessment of the ecological risks of soil and water quality degradation may increasingly become the yardstick used to measure the damage of agricultural productivity caused by soil and water quality degradation.

Studies of (Beckford et al., 2011) define sustainable agriculture as farming practices which limit and mitigate the degradation and depletion of resources while increasing local food production, enhancing food security and securing rural livelihoods and quality of life through employment and income generation. Sustainable agriculture therefore, has both environmental and economic impacts as it alleviates rural poverty and promotes rural development while conserving natural resources and protecting and restoring the environment. They argue that commercial cultivation of crops inevitably causes alterations of natural resources and ecosystems. Sustainable agricultural practices must therefore, include activities which attempt to restore and rehabilitate degraded farmland and environments.

According to (Testa et al., 2015), evaluation of the financial sustainability of organic lemon production by comparing it with the conventional one. Financial analysis has been carried out in a case study on the northwestern coast of Sicily, considering a 50-year economic life of an orchard. The results, per hectare of area, showed a clear advantage of organic lemon orchard. This was due to fewer labor requirements and to greater market appreciation for organic products that better ensured a premium price. Moreover, financial indicators of organic lemon orchards and the deployment of environmental-friendly inputs in the production process render these farms competitive and eco-friendly.

The present work, allows visualizing the extent of this pollution, by focusing on agricultural nitrogen 
inputs based on quantification, classification, zoning and spatialization through the establishment by ordinary kriging of a map showing spatial distribution of nitrates recorded at 48 wells distributed over the alluvial aquifers, which is located in the plain of study, these wells having been experienced in hydrochemical campaign during May 2012. In parallel, a field survey was conducted on the applied agricultural practices, including the fertilizer types, doses applied to ground and irrigation modes. Evaluation of nitrogen inputs to soils of the plain from agricultural sources, helped to understand deducted zoning map according to the different levels of nitrates. This work also examined the water quality of the most important and exploited groundwater in the plains based on test results conducted on all wells sampled, through the spatial evolution of the parameters analyzed (EC, $\mathrm{Cl}$ and $\mathrm{NO} 3$ ).

\section{Materials and Methods}

\section{Presentation of the Study Area}

The study plains is located north-west of Algeria, about $200 \mathrm{~km}$ west of Algiers and $30 \mathrm{~km}$ as the crow flies from the Mediterranean. It is located between $36^{\circ} 3^{\prime}$ $\& 36^{\circ} 15^{\prime}$ north latitude and $01^{\circ} 4^{\prime} \& 01^{\circ} 27^{\prime}$ east longitude (Fig. 1) and covers an area of approximately $270 \mathrm{~km}^{2}$ in the Western Middle Cheliff basin. It is bordered in the south by the massif of Ourasenis and the north by the mountains of Medjadja and includes land for $6 \mathrm{~km}$ upstream of Oum Drou up to $3 \mathrm{~km}$ downstream of Boukadir. It extends in the central area to Ouled Fares in the tributary valley Oued Ouahrane.

The region is characterized by a semi-arid climate with hot summers and cold winters despite its proximity to the sea. The mountains of Dahra form an isolating barrier of the Cheliff basin from the regulatory influence of the Mediterranean over $70 \mathrm{~km}$. the difference between the recorded temperature, maximum in July $\left(29^{\circ} \mathrm{C}\right)$ and lowest in January $\left(10^{\circ} \mathrm{C}\right)$, is considerable $\left(19^{\circ} \mathrm{C}\right)$. The results of the water balance for the year 2012, by the method of Thornthwaite (Remenieras, 1980) on data collected from the rainfall station of Chlef (ANRH, 2012) provide an evapotranspiration of 1230 $\mathrm{mm}$ and a high enough water deficit $(947 \mathrm{~mm})$. Infiltration deducted from the excess water is only $10 \%$ of total rainfall measured at $320 \mathrm{~mm}$. Intensive use of waters of the aquifer threatens the reserves of this potential resource. The average annual volume of exploitation is $30.09 \mathrm{hm}^{3}$ (ABH-CZ, 2004), $86 \%$ for drinking water supply, $12 \%$ for irrigation and $1 \%$ for industrial uses.

From a geological point of view, the plain of Middle Cheliff corresponds to a sedimentary basin orientation East-West containing age detrital sediments Sub-
Pliocene Quaternary forming the embankment of the valley (Fig. 2). These sediments include clays and thick marls with sands, gravels and conglomerate (Perrodon, 1957; Mattauer, 1958). The lithological descriptions drillings (ANRH, 2004) indicate that under soil area, an important layers of clayey materials (described as plastic or compact clay, silty or sandy clay) are localized with average and maximum thicknesses recorded are 23 and $50 \mathrm{~m}$, respectively. This thick clayey profile which is in a big part of the central zone of the plain offers a low permeability not allowing a sufficient recharge of aquiferous horizon. The average permeability of the sediments Plio-Quaternary is $5.10^{-4} \mathrm{~m} \mathrm{sec}^{-1}$, the specific rates are generally higher than $2 \mathrm{l} / \mathrm{s} / \mathrm{m}$ and up to $30 \mathrm{l} / \mathrm{s} / \mathrm{m}$ (Scet Agri, 1984a). On the contrary, on the borders of the plain (Ouled Fares in the North to the Abiadh Medjadja in the East and Sobha in the West), the unsaturated zone formations are more permeable. The lower limit is constituted by impermeable hydrogeological formations, argilo-marly of the Miocene over all the surface of the aquifer.

The piezometric map established in 2004 (Bettahar et al., 2009) shows hydro-isohypse closed curves in center of the plain and open towards the borders. This indicates a supply from the borders toward the plain. Piezometric lines perpendicular to the axis of the valley converge to the center of the plain before taking an East-West parallel direction over the Oued Cheliff. Depressions are observed in the lower valley of Oued Ouahrane due to intensive pumping effect for agricultural purposes. In addition to the meteoric water, groundwater receives a large South supply from lithothamnium Miocene limestone manifested by a high gradient $(1.7 \%)$ from South to North. It received another lower supply from northern foothills areas belonging to the Pliocene formations with a gradient of $0.8 \%$ (Achour, 1997). The part of irrigation water that returns to the aquifer is estimated at $20 \%$ of the total volume used for this purpose (Scet Agri, 1984b).

The plain of Western Middle Cheliff is an agricultural vocation, it covers an area of 27.000 ha, in which agricultural area reconquers 10100 ha (37.4\%) are actually irrigated (ONIDC, 2012).

Dominated by citrus, in particular by the production of oranges, arboriculture with $38.61 \%$ of irrigated surfaces is the most important speculation (Fig. 3).

It is concentrated in the central part of the perimeter on the right bank of the Oued Cheliff. Vegetable growing occupies second position (34.56\%), it is located mainly near the borders of the study area (Abiadh Medjadja, Ouled Fares, Sobha, Oued Sly and Oum Drou). The potato is the dominant speculation, it covers about $60 \%$ of this surface. Cereal represent $26.56 \%$ and is concentrated in the foothills, distributed between the wheat, which occupies $90 \%$ of the surface and the barley with $10 \%$. They depend of vegetable crops, potatoes in 
particular, occupies an area ranging from 500 to 800 ha. After harvest of potatos, cereals occupies the same area with the same mode of irrigation which is by spraying, by individual wells water with nitrate concentrations which far exceed (for the majority of wells) the potability threshold (50 $\mathrm{mg} \mathrm{L}^{-1}$ ) (Bettahar and Douaoui, 2007).

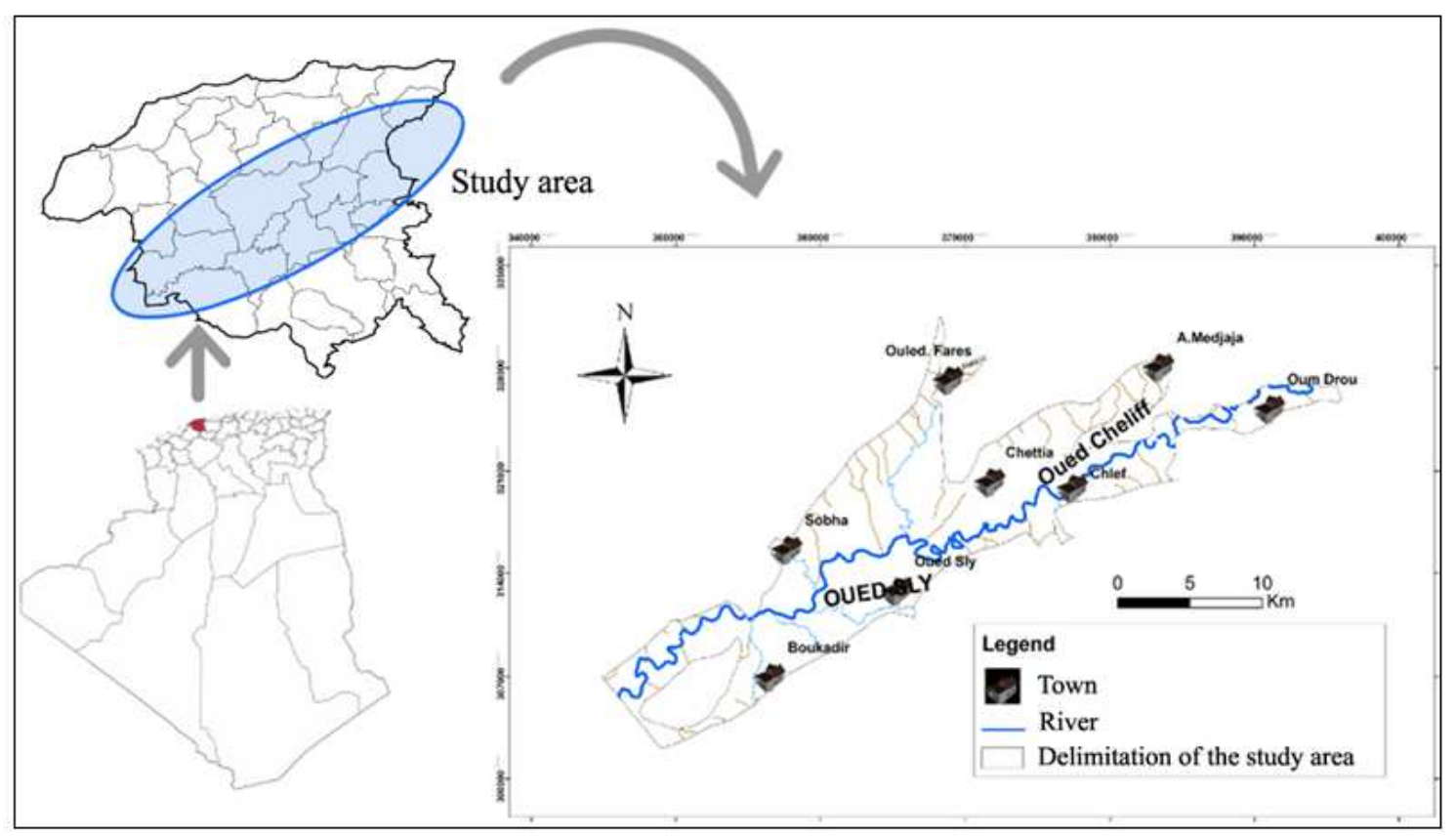

Fig. 1. Location of the study area

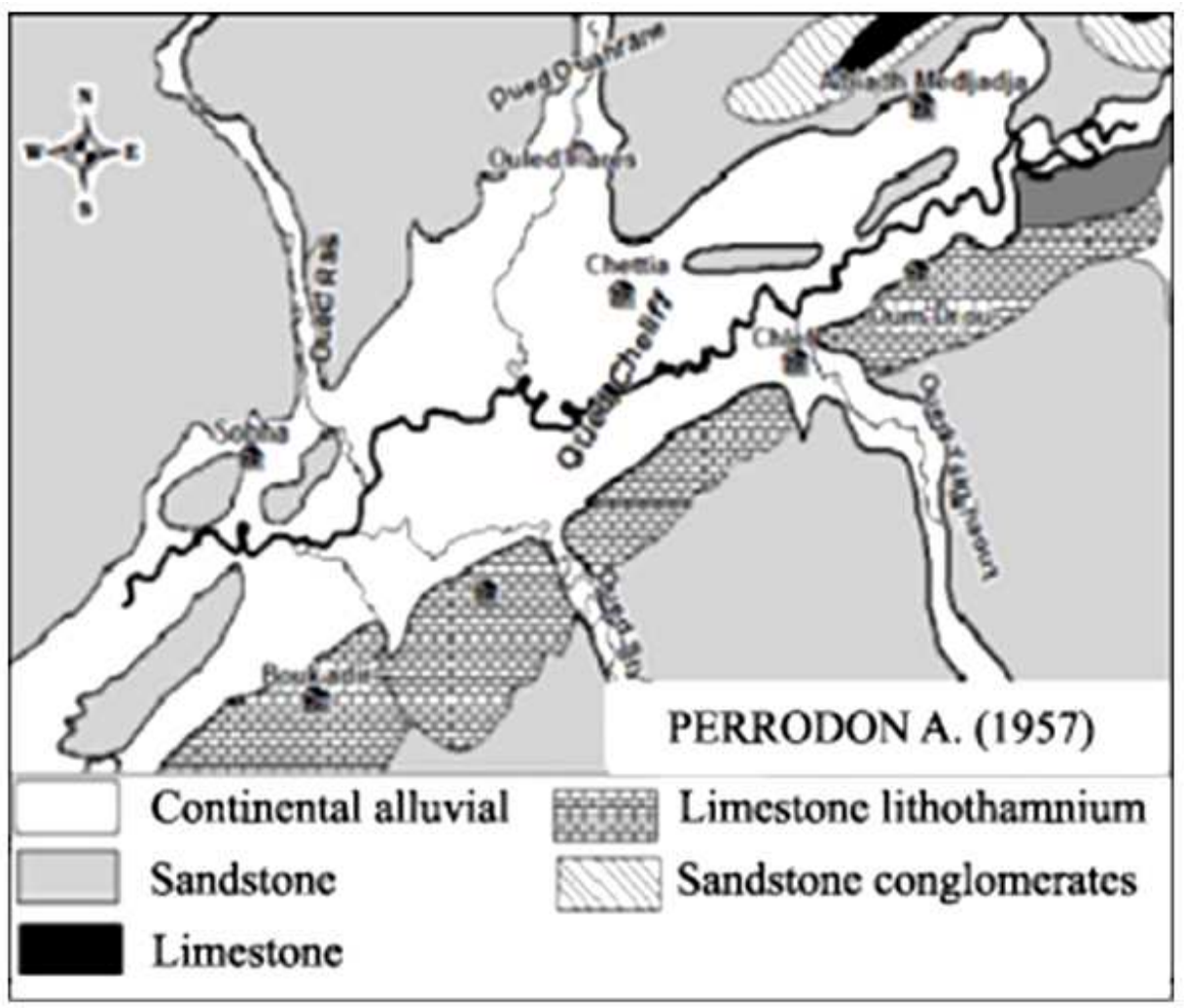

Fig. 2. Geology of the study area 


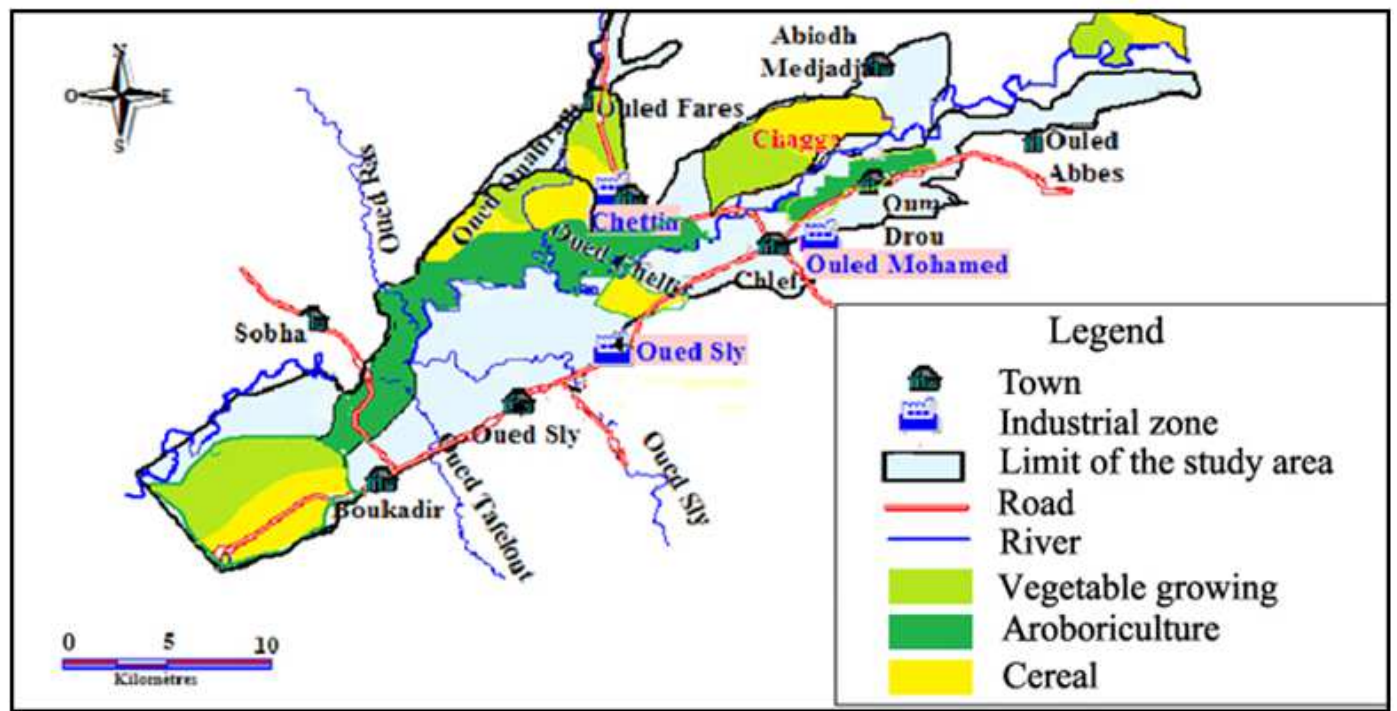

Fig. 3. Spatial distribution of speculation in the perimeter of the Western Middle Cheliff

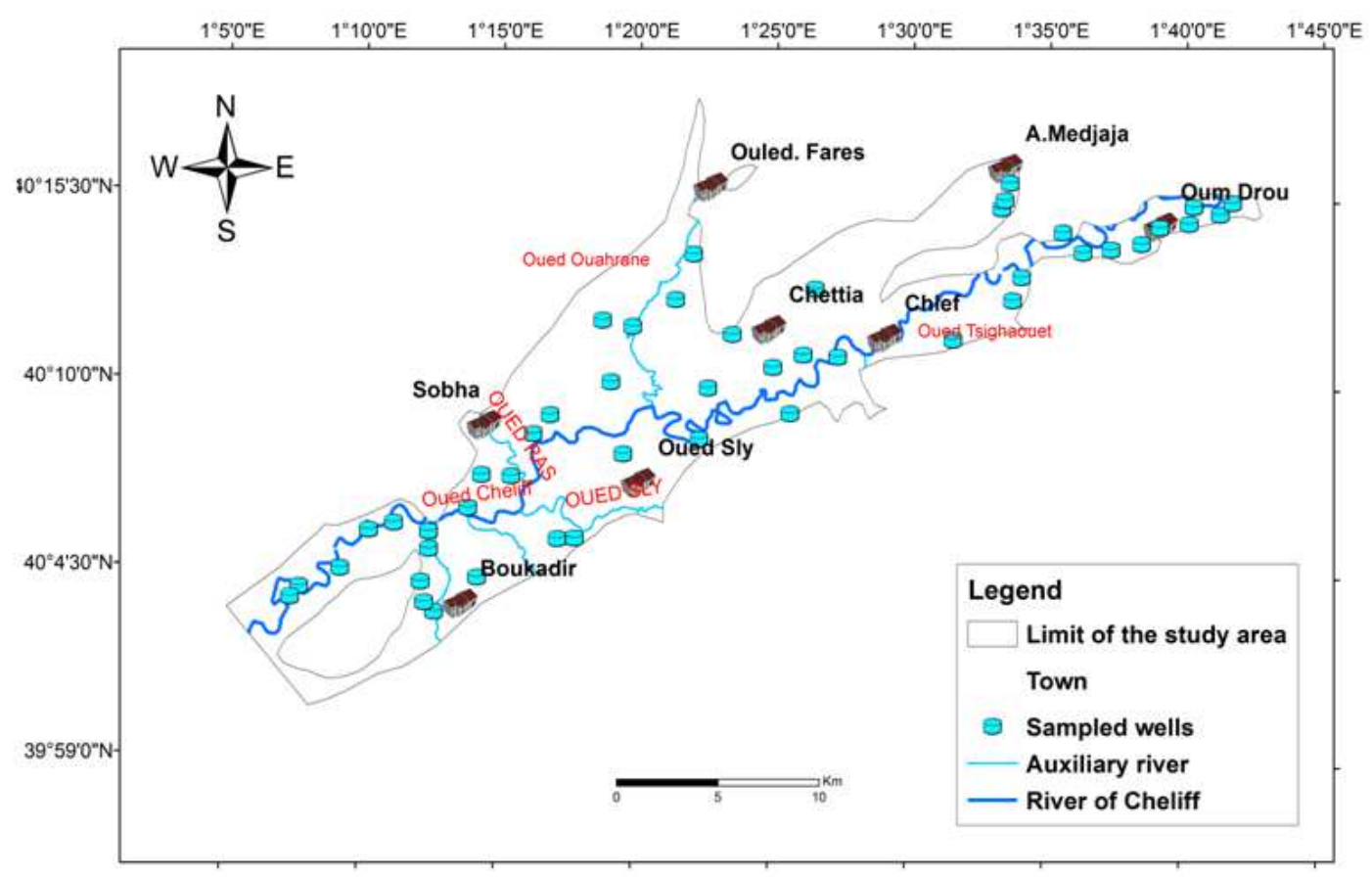

Fig. 4. Location of sampled wells

\section{Sampling and Analysis Methods}

A set of eight monthly campaigns was made from October 2011 to May 2012 in collaboration with the Cheliff-Zahrez Basin Agency in the context of the updating the PDARE database retained in the program of the Algerian-German cooperation for water resources sector. This involved the establishment of an observation network at the aquifer of study, chosen as a pilot aquifer, usually a total of 39 irregularly distributed wells.

Other campaigns covered a higher number (up to 48 wells), one in a high water period (December) and other in low water period (May), to allow spatial tracking pollution by nitrates geostatistical approach. The samples were concentrated in areas of foothills (intensive vegetable growing) and more distant to the center (fruit growing) as shown in the sampling plan presented in (Fig. 4). 


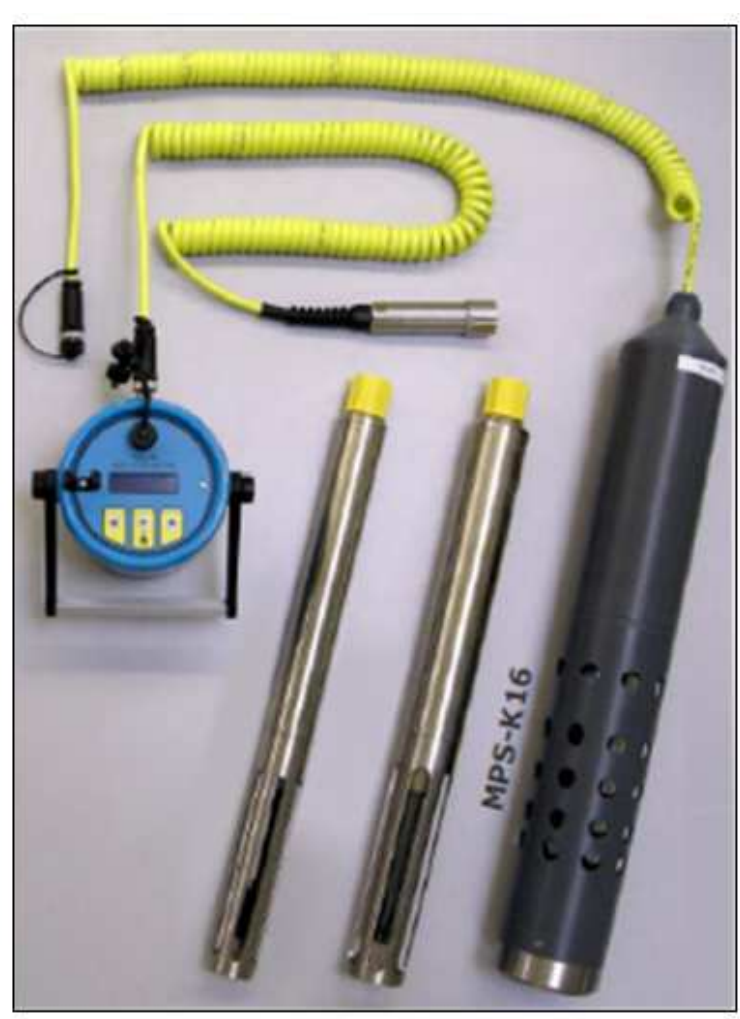

Fig. 5. Portable instrument SEBA MPS-K16

The physico-chemical and chemical parameters were measured on area via a portable instrument for water quality measurement (with a multi-parameter probes) SEBA MPS-K16 (Fig. 5). The SEBA multi-parameter system has been developed as a mobile field laboratory especially for determination of water quality parameters in surface water, with fast and precise acquisition of various water quality parameters. The current measured values are clearly displayed. This portable instrument allow the measurement of the Temperature (T), pH, Electric Conductivity (EC), Chloride $\left(\mathrm{Cl}^{-}\right)$and Nitrate $\left(\mathrm{NO}_{3}{ }^{-}\right)$.

\section{Results and Discussion}

\section{Physico-Chemical Composition of Groundwater}

The underground waters are highly mineralized $(900<\mathrm{EC}<8700 \mu \mathrm{S} / \mathrm{cm})$ compared to the potability standard $(400 \mu \mathrm{S} / \mathrm{cm})$, with neutral $\mathrm{pH}(7<\mathrm{pH}<8)$ which is in the potability standard and with a domination of Sodium and Calcium for the Cations and Chloride and Sulfate for Anions. The average value of total hardness oscillates around $110^{\circ} \mathrm{F}$ classifying these waters in the very hard water category not recommended for domestic use. This result confirms that obtained in a previous study (Bettahar and Douaoui, 2001).

\section{Spatial Evolution of the Measured Parameters}

The established maps for the parameters measured during both periods (high waters and low waters), shows that the highest values of the electrical conductivity characteristic (Fig. 6) particularly the extensions SouthEast and South-West and a small range in the center. The average is $4077 \mu \mathrm{S} \mathrm{cm} \mathrm{cm}^{-1}$, the maximum and minimum reach respectively 19770 and $1211 \mu \mathrm{S} \mathrm{cm}^{-1}$ exceeding the standard recommended for drinking water supply. These high values may be due to the dissolution of evaporite formations of Dahra and Triassic ante-nappes of Ouarsenis and to the dissolution of silicate minerals (Achour, 1997).

High levels of chloride (Fig. 7) is particularly observed at the South-West extension of the study area probably due to the dissolution of evaporite formations of Triassic ante-nappes of Ouarsenis and to the hydrolysis of silicate minerals. Concentrations are high enough, between a minimum of $176 \mathrm{mg} \mathrm{L}^{-1}$ and a maximum of $4217 \mathrm{mg} \mathrm{L}^{-1}$. Average oscillates around $694 \mathrm{mg} \mathrm{L}^{-1}$ exceeding the potability standard (200 $\mathrm{mg} \mathrm{L}^{-1}$ ). The high levels of chlorides registered are due to the special characteristics of this element that does not fit in the chemical precipitation phenomena, is not adsorbed by the geological formations and it is very mobile. This parameter migrates at the same rate as nitrates, but they are not destroyed as they migrate (El Tabach, 2005). The anthropic origin of chloride which is related to wastewater (Achour, 1997) and domestic waste (Tahraoui Douma, 2006) cannot be neglected in the study area.

High levels of $\mathrm{NO}_{3}$ (Fig. 8) are observed in the South-West extensions (Oued Sly, Boukadir and Sobha) and South-East (Oum Drou) and in the lower valley of Oued Ouahrane, characterized by a high agricultural activity where grounds are the most permeable $\left(\mathrm{K}=10 \mathrm{~cm} \mathrm{~h}^{-1}\right)$. The center of the plain show low nitrate concentrations (less than or close to the potability standard) due to the existence of clay formations that prevent nitrate infiltration to groundwater. These zones cultivated in arboriculture undergo a reasoned fertilization and are irrigated from waters of dams (Sidi Yacoub and Oued Fodda) of which the content of nitrates remains lower than 10 $\mathrm{mg} \mathrm{L}^{-1}$ (ABH-CZ, 2004). Values recorded during the study campaign show that $48 \%$ of water points sampled exceed the potability threshold $\left(50 \mathrm{mg} \mathrm{L}^{-1}\right)$ with concentrations ranging from a minimum of $3 \mathrm{mg}$ $\mathrm{L}^{-1}$ and a maximum of $367 \mathrm{mg} \mathrm{L}^{-1}$ and an average of $73 \mathrm{mg} \mathrm{L}^{-1}$. The coefficient of variation is high enough proving of the anthropic origin of this element mainly related to the application of nitrogen fertilizers and irrigation water. 
Fig. 6. Spatial evolution of the Electrical Conductivity (EC)

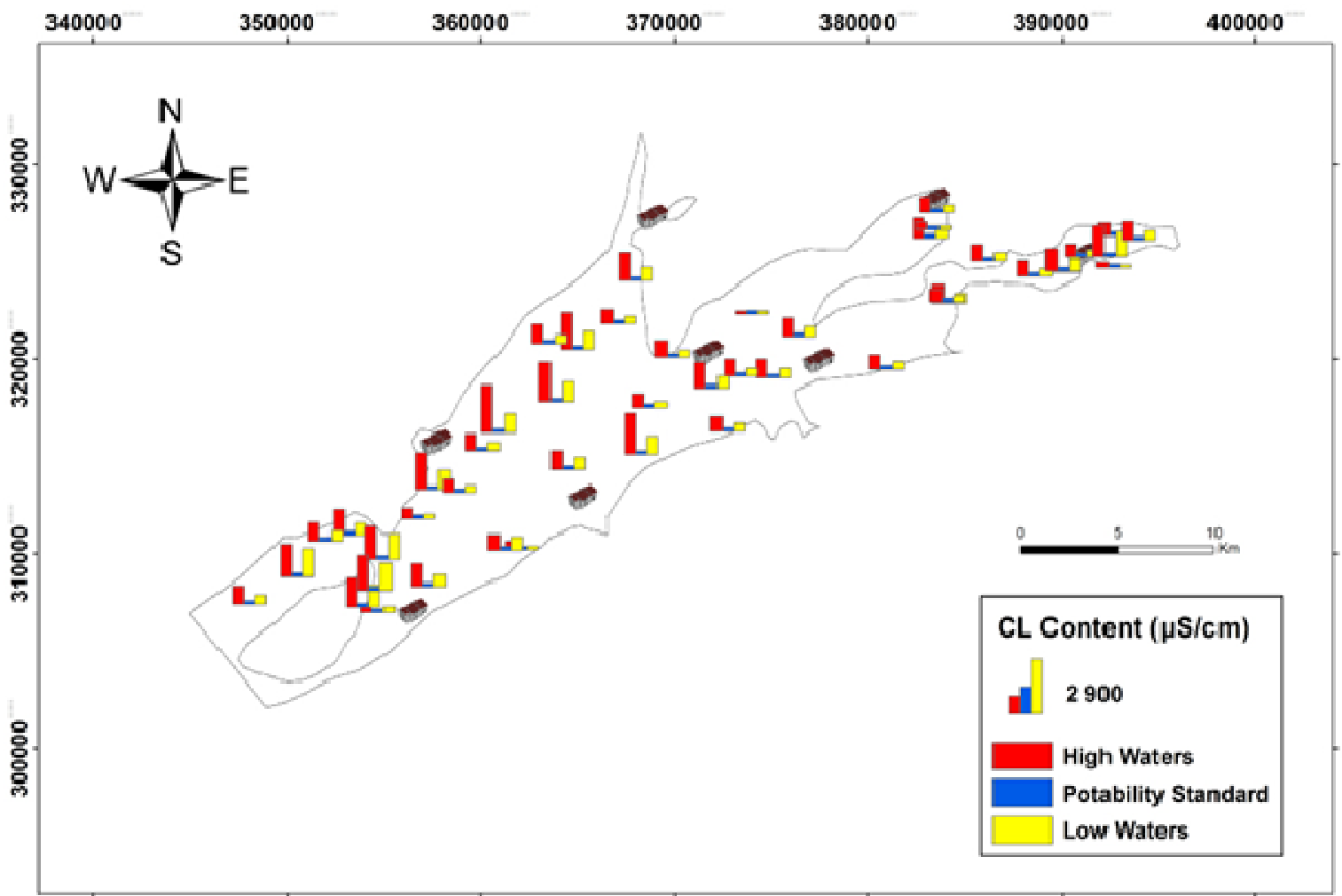

Fig. 7. Spatial evolution of chloride (CL) 


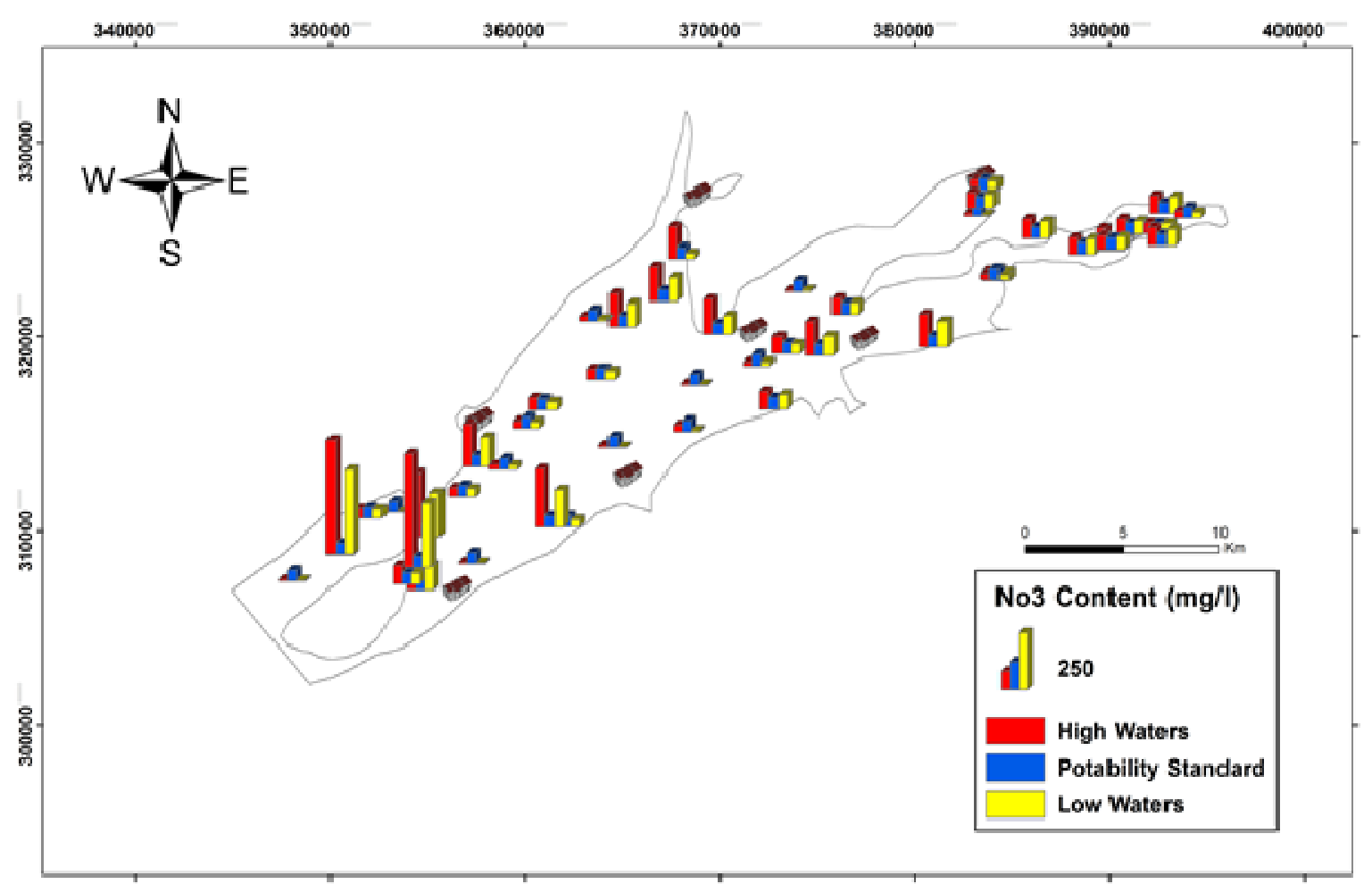

Fig. 8. Spatial evolution of nitrates $\left(\mathrm{NO}_{3}\right)$

Quantification of Nitrogen Inputs in the Study Area

\section{Nitrogen Input from Fertilizers}

A field survey was conducted during 2012 with many farmers to identify different agricultural practices in this perimeter which covering more than 27.000 hectares of surface. Industrial fertilizers and in particular the NPK 15.15.15 are predominant for almost all the exploitations with annual average doses of $700 \mathrm{~kg} \mathrm{ha}^{-1}$ for vegetable growing and up to 1000 $\mathrm{kg} \mathrm{ha}^{-1}$ for potatoes, used as a base fertilizer. Other fertilizers such as urea (46\%) which is used as a cover fertilizer with doses ranging from $50 \mathrm{~kg} \mathrm{ha}^{-1}$ for cereals to $500 \mathrm{~kg} \mathrm{ha}^{-1}$ for arboriculture and up to 600 $\mathrm{kg} \mathrm{ha}{ }^{-1}$ for vegetable growing. These values were used to estimate nitrogen inputs to soils of the plains by multiplying the dose of fertilizer spread of speculation by the corresponding area.

\section{Nitrogen Input from Irrigation Water}

The massive reduction of surface water during the 90 s led to reserve the water of dams for priority of arboriculture. Groundwater assure irrigation in the perimeter of almost $80 \%$ of irrigated areas. $94 \%$ of cereal crops are irrigated from rain water, but during periods of drought a rate of $6 \%$ is provided by irrigation water from wells of which nitrate concentrations are, for the majority, above the potability standard $\left(50 \mathrm{mg} \mathrm{L}^{-1}\right)$.

The potato constitutes $70 \%$ of vegetable growing and is irrigated at a rate of $3200 \mathrm{~m}^{3} /$ ha/year. Cucurbits constitute the rest and are irrigated at a rate of 1200 $\mathrm{m}^{3} /$ ha/year. As for cereals, they are irrigated at 1000 $\mathrm{m}^{3} /$ ha/year. From the following formula (Martin, 2003), we can estimate the quantity of nitrogen in this water using Equation 1:

$X_{N}=\frac{\left[\mathrm{NO}_{3}^{-}\right] \times Q_{\text {irig }}}{4,43 \times 10^{2}}$

Where:

$X_{N}=$ The quantity of annual nitrogen provided by the irrigation water $(\mathrm{kgN} / \mathrm{ha} /$ year $)$

$\mathrm{NO}_{3}=$ The nitrate concentration in water well $(\mathrm{mg} / \mathrm{l})$

$Q_{\text {irrig }}=$ The annual quantity of irrigation water (mm/year)

$4.43=$ The ratio of the molar masses $\mathrm{NO}_{3} / \mathrm{N}$

The Fig. 9. shows that annual nitrogen inputs to soils of the plains are valued at $1958.83 \mathrm{~T}, 95 \%$ are attributed to nitrogen fertilizer and the rest to irrigation water. 


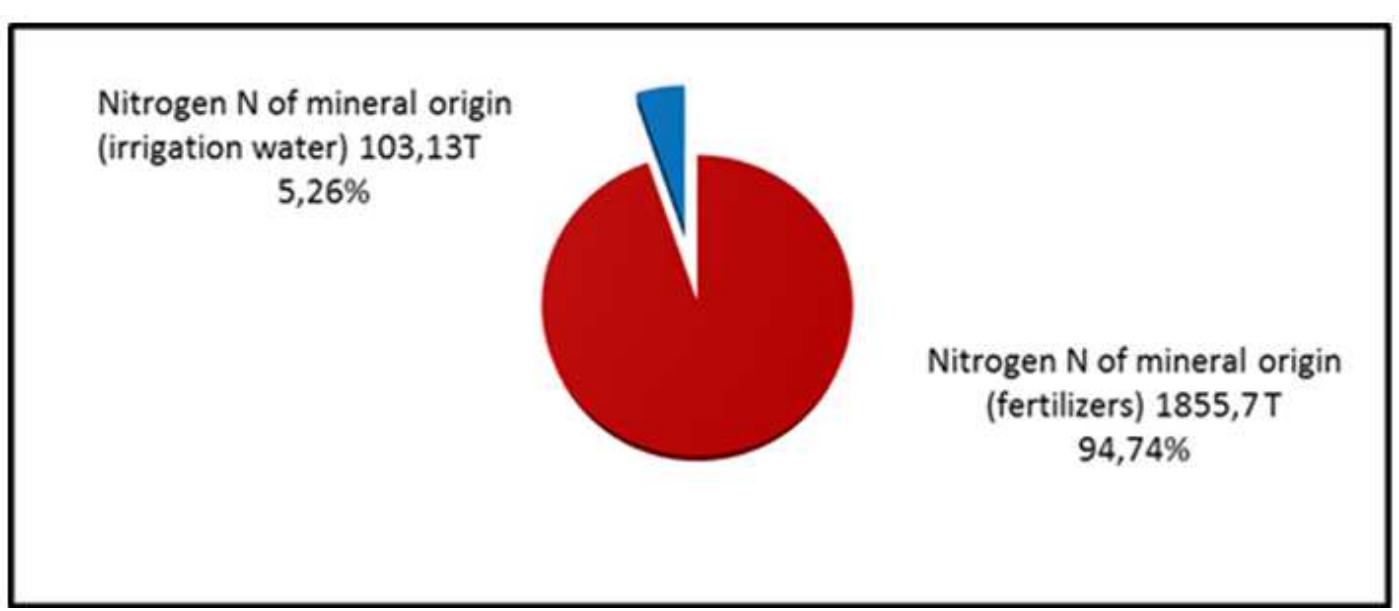

Fig. 9. Annual mineral nitrogen contribution on the perimeter of Western Middle Cheliff

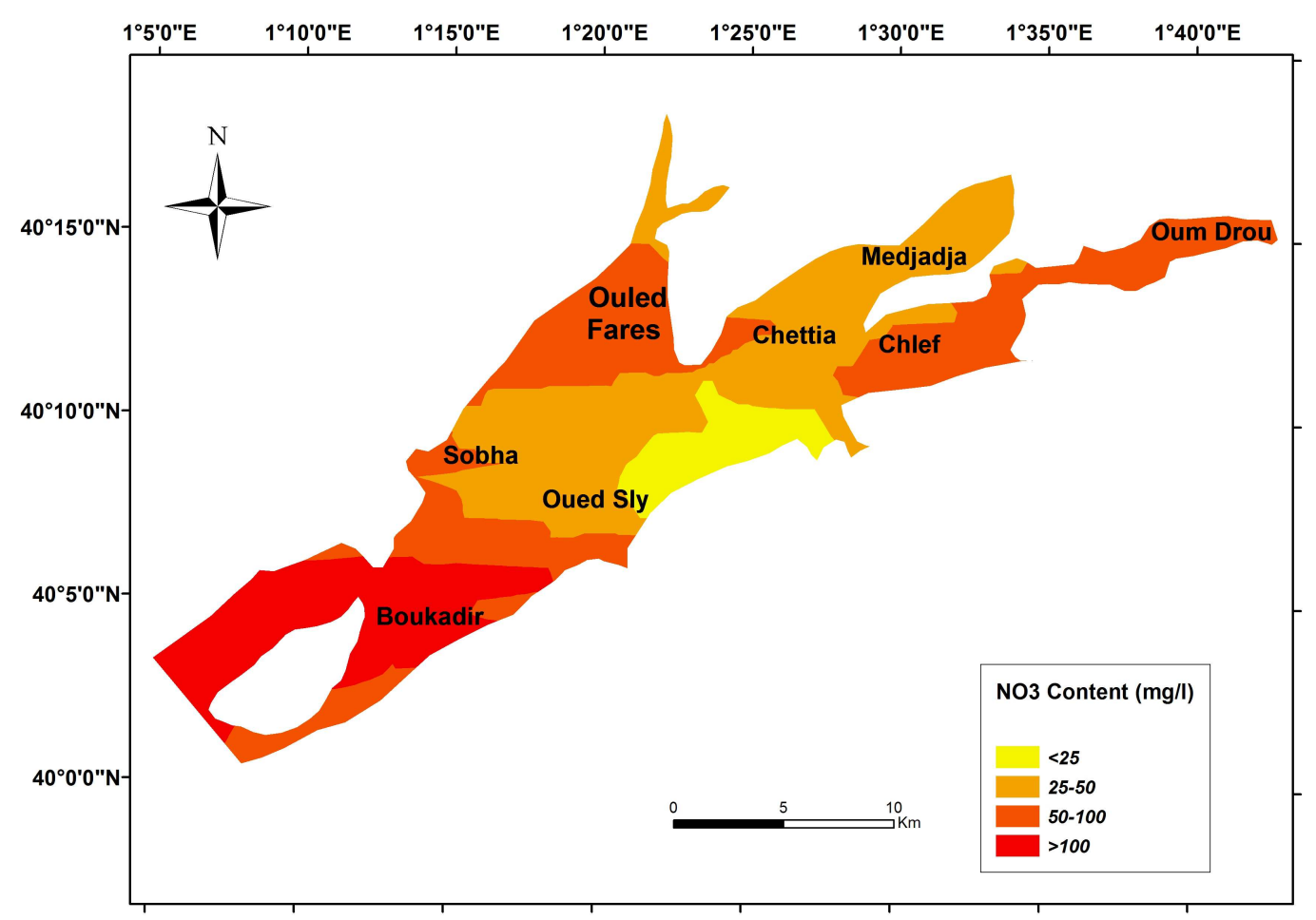

Fig. 10. Map of nitrates established by ordinary kriging (May 2012)

\section{Spatial Evolution of Nitrates}

The map of nitrates established by ordinary kriging for campaign data in May 2012 shows that the most affected areas $\left(\mathrm{NO}_{3}-50 \mathrm{mg} \mathrm{L}^{-1}\right)$ are those for which the level of intensification of nitrogen fertilization (areas of vegetable growing) Is the highest. The zones of Chettia and Sobha and the lower valley of Oued Ouahrane where old alluviums and the foothills soils are characterized by the highest permeability ( $\mathrm{K}$ Henin $10 \mathrm{~cm} \mathrm{~h}^{-1}$ ). The sensitivity of these soils nitrate leaching phenomenon is, therefore, very high. In these same areas, farming practices are the most intensive and connection rates to the lowest sanitation (Bettahar et al., 2009). As for the South-West extension (downstream of Oued Sly and cuvette of Boukadir), it supports waters with high nitrate levels despite the very fine texture of the soil. This is due to the accumulation of pollution in the direction of flow upstream of the aquifer to the downstream hydraulic. The levels are lower in the center of the valley, subsoils with fine texture and the permeability of which varies 
between 0.5 and $2 \mathrm{~cm} \mathrm{~h}^{-1}$. This could highly reduce the propagation of deep nitrates (Fig. 10).

\section{Conclusion}

The results obtained in this study show that the concentrations are high enough for most of chemical and physico-chemical elements in waters of the groundwater, which are from matrix or anthropogenic origin. Concentrations that frequently exceed standards of potability set by the Council of the European Communities (CEC).

The highest nitrate levels concentrate mainly in Boukadir downstream and in the lower valley of Oued Ouahrane (Ouled Fares and Chettia). Indeed, the total nitrogen inputs (from fertilizer and irrigation water) are the highest in these two areas and relatively high in Boukadir downstream. Soil type in these areas also play an important role in the nitrate leaching, considering that, their permeabilities are the highest $\left(10 \mathrm{~cm} \mathrm{~h}^{-1}\right)$.

The areas providing quality waters conforms to the standard (NO3 $<50 \mathrm{mg} \mathrm{L}^{-1}$ ) especially cover the center of the valley where the irrigation of fruit farming (particularly citrus) is from the waters of Sidi Yacoub and Oued Fodda dams when average nitrate concentrations remain low and oscillate around $10 \mathrm{mg}$ $\mathrm{L}^{-1}$ (ABH-CZ, 2004). In addition, nitrogen fertilization applied to this speculation remains reasoned compared to that applied for vegetable crops concentrated in the foothills of the valley.

Finally, the areas classified by descending order of nitrate risk include respectively: Ouled Fares, Chettia, Sobha, Boukadir, Chlef, Oum Drou and Medjadja. This corresponds exactly to a decreasing input of total mineral nitrogen (fertilizer and irrigation water).

\section{Funding Information}

The authors have no support or funding to report.

\section{Author's Contributions}

All authors equally contributed in this work.

\section{Ethics}

This article is original and contains unpublished material. The corresponding author confirms that the other author has read and approved the manuscript and no ethical issues involved.

\section{References}

ABH-CZ, 2004. Cadastre hydraulique, Mission I. Agence de Bassin Hydrographique CheliffZahrez. Algérie.
ABH-CZ, 2012. Cadastre hydraulique, Mission II. Agence de Bassin Hydrographique Cheliff-Zahrez, Algérie.

ANRH, 2012. Pollution par les nitrates. Agence Nationale des Ressources Hydrauliques, Algérie.

Achour, F., 1997. Conditions hydrologiques et disponibilité en eau en région semi-aride: Application de méthodologies nouvelles au bassin du Cheliff, Algérie. Thèse de Doctorat, Université Franche-Comté, France.

ANRH, 2004. Annuaire hydrogéologique de la nappe alluviale du haut et moyen Cheliff. Agence Nationale des Ressources Hydrauliques, Algérie.

Beckford, C., D. Campbell and D. Barker, 2011. Sustainable food production systems and food security: Economic and environmental imperatives in Yam cultivation in Trelawny, Jamaica. Sustainability, 3: 541-561. DOI: 10.3390/su3030541

Bettahar, N. and and A. Douaoui, 2001. Evolution spatial de la dureté de l'eau dans les plaines du Cheliff. Utilisation de l'approche géostatistique. Bull. Ass. Geogr. Amenage. Territ., 9: 115-121.

Bettahar, N. and A. Douaoui, 2007. Effect of the pedoclimatic conditions on nitrogen assessment. Arab Water World, 8: 41-42.

Bettahar, N., A. Ali Benamara, A. Kettab and A. Douaoui, 2009. Risque de pollution nitratée des zones semi-arides: Cas de la vallée du moyen Cheliff occidental (Nord Algérien). Rev. Sci. Eau., 22: 69-78. DOI: 10.7202/019824ar

Boudjadja, A., M. Messahel and H. Pauc, 2003. Ressources hydriques en Algérie du Nord. Revue des Sciences de l'Eau., 16: 286-304. DOI: $10.7202 / 705508$ ar

Chabour, N., 2004. La surexploitation des eaux souterraines dans les plaines littorales: la nappe de Télizza dans la plaine de Collo (Nord-Est algérien). Sci. Technol. B-N, 22: 127-132.

De Waele, J., I.A. Nyambe, A. Di Gregorio, F. Di Gregorio and S. Simasiku et al., 2004. Urban waste landfill planning and karstic groundwater resources in developing countries: The example of Lusaka (Zambia). J. Afr. Earth Sci., 39: 501-508.

DOI: 10.1016/j.jafrearsci.2004.07.014

Debieche, T.H., 2002. Evolution de la qualité des eaux (Salinité, Azote et Métaux lourds) sous l'effet de la pollution saline, agricole et industrielle (application à la basse de la plaine Seybouse-Nord-Est Algérien). Thèse de Doctorat, Université de Franche-Comté, France.

Djabri, L., 1996. Mécanismes de la pollution et vulnérabilité des eaux de la Seybouse. Origines géologiques, industrielles, agricoles et urbaines. Thèse de Doctorat, Es-Sciences, University Annaba. 
Elmi, A.A., C. Madramootoo, M. Egeh and C. Hamel, 2004. Water and fertilizer nitrogen management to minimize nitrate pollution from a cropped soil in South Western Quebec, Canada. Water Air Soil Pollt., 151 : 117-134.

DOI: 10.1023/B:WATE.0000009910.25539.75

El Tabach, E., 2005. Etude de l'impact d'une pollution accidentelle et d'une pollution agricole sur les ressources en eau souterraine. Thèse de Doctorat. Ecole Polytechnique Universitaire de Lille.

Feng, Z.Z., X.K. Wang and Z.W. Feng, 2005. Soil N and salinity leaching after the autumn irrigation and its impact on groundwater in Hetao Irrigation District, China. Agric. Water Manage., 71: 131-143. DOI: 10.1016/j.agwat.2004.07.001

Ikhlef, S., 2008. Etude de la pollution de la nappe alluviale du haut Cheliff par les nitrates. Mémoire de Mag., Univ. de Chlef.

Kherici, N., 1993. Vulnérabilité à la pollution chimique des eaux souterraines d'un système de nappes superposées en milieu industriel et agricole (Annaba - La Mafragh) Nord-Est Algérien. Th. Doct. EsSciences, Univ. Annaba.

Martin, C., 2003. Mécanismes hydrologiques et hydrochimiques impliqués dans les variations saisonnières des teneurs en nitrate dans les bassins versants agricoles. Approche expérimentale et modélisation. Thèse Doctorat, Ecole de Renne 1, France.

Mattauer, M., 1958. Étude géologique de l'Ouarsenis oriental (Algérie). Thèse Es sciences, Université de Besançon, France.

Nafa, K., 1985. Approche géophysique des problèmes d'hydrodynamique et d'invasion marine en milieu souterrain. Exemple des plaines d'Annaba, de la Mitidja et de la Baie d'Alger. Th. Doct. EsSciences, Univ. S.T.H.B. d'Alger.

Nkhuwa, D.C.W., 2003. Human activities and threats of chronic epidemics in a fragile geologic environment. Phys. Cherm. Earth, 28: 1139-1149. DOI: $10.1016 /$ j.pce.2003.08.035

Nkhuwa, D.C.W. and F. Tembo, 1998. Groundwater recharge and susceptibility to pollution of the Lusaka marble aquifer. From Isotope techniques in the study of environmental change. International Atomic Energy Agency (IAEA).
ONIDC, 2012. Office National d'Irrigation et de Drainage Centre.

Perrodon, A., 1957. Étude géologique des bassins néogènes sublittoraux de l'Algérie Nord Occidentale. Thèse de Doctorat, Université d'Alger, Algérie.

Remenieras, G., 1980. L'Hydrologie de L'ingénieur. Eyrolles, 2nd Edn., Paris, pp: 455.

Salem, Z., H. Lebik, W.K. Cherafa and K. Allia, 2007. Valorisation of olive pits using biological denitrification. Desalination, 204: 72-78. DOI: 10.1016/j.desal.2006.04.025

SCET AGRI, 1984a. Hydrologie-Hydrogéologie et bilan des ressources. Étude du réaménagement et de l'extension du périmètre du moyen Chéliff. Rap A1.1.2. Pub. Ministère de l'Hydraulique, Algérie.

SCET AGRI, 1984b. Bilan des ressources en sol. Étude du réaménagement et de l'extension du périmètre du moyen Cheliff. Rap A1.2.1. Pub. Ministère de l'Hydraulique, Algérie.

Shiklomanov, I.A., 1997. Assessment of water resources and availability in the world. In Comprehensive assessment of the freshwater resources of the world. Stockholm, Stockholm Environment Institute.

Tahraoui Douma, N., 2006. Analyse des Déchets Ménagers Solides de la Ville de Chlef. Méthodes de Traitement-Mémoire de Magister, Université de Chlef.

Testa, R., M. Foderà, A.M. Di Trapani, S. Tudisca and F. Sgroi, 2015. Choice between alternative investments in agriculture: The role of organic farming to avoid the abandonment of rural areas. Ecol. Eng., 83: 227-232.

DOI: $10.1016 /$ j.ecoleng.2015.06.021

Yapo, O.B., V. Mambo, E.J.C. Meledje Djedjess, M.J. Ohou and A. Seka, 2009. Searching for parameters optimising the biological denitrification of nitrateand ammonium-rich well waters by private slow sand filtration reactors. Eur. J. Scientific Res., 26: 565-576. 